\title{
ФРАЗЕОЛОГІЗМИ З НАЗВАМИ ВЕЛИКОДНІХ СВЯТ В УКРАЇНСЬКОМУ ДІАЛЕКТНОМУ МОВЛЕННІ
}

\author{
НАТАЛІЯ КОВАЛЕНКО \\ Кам'янець-Подільський національний університет імені Івана Огієнка, \\ Кам'янець-Подільський - Україна \\ kovalenko.bor@gmail.com; ORCID: 0000-0002-7810-1982 \\ ІРИНА ЦАРЮК \\ Кам'янець-Подільський національний університет імені Івана Огієнка, \\ Кам'янець-Подільський - Україна \\ iratsaruk13@gmail.com; ORCID: 0000-0002-7843-1631 \\ FRAZEOLOGIZMY ZAWIERAJĄCE NAZWY ŚWIĄT \\ WIELKANOCNYCH W GWARACH UKRAIŃSKICH \\ NATALIA KOWALENKO \\ Narodowy Uniwersytet imienia Iwana Ohijenki w Kamieńcu Podolskim, \\ Kamieniec Podolski - Ukraina \\ IRYNA CARIUK \\ Narodowy Uniwersytet imienia Iwana Ohijenki w Kamieńcu Podolskim, \\ Kamieniec Podolski - Ukraina
}

STRESZCZENIE. Artykuł poświęcono etnokulturowym właściwościom frazeologizmów terytorialnych, które zawierają nazwy kolejnych etapów Świąt Wielkanocnych. Wyjaśniono semantyczne podstawy ich tworzenia, ustalono, że w języku potocznym stale dochodzi do odtworzenia form i semantyki frazeologizmów, powstawania nowych motywacji, rozwoju wariantów poprzez izoleksy na podstawie już istniejących konstrukcji językowych.

Słowa kluczowe: frazeologizm, semantyka, motywacja, dialekt, Święta Wielkanocne.

\section{PHRASEOLOGICAL UNITS WITH THE NOMINATIONS \\ OF EASTER HOLIDAYS IN UKRAINIAN DIALECTAL LANGUAGE}

\section{NATALYA KOVALENKO}

Kamyanets-Podilskiy Ivan Ohiyenko State University, Kamyanets-Podilskiy — Ukraine

IRYNA TSARIUK

Kamyanets-Podilskiy Ivan Ohiyenko State University, Kamyanets-Podilskiy — Ukraine

ABSTRACT. In the article the ethno-cultural peculiarities of the areal phraseological units, which contain the names of stages or activities during the Easter holidays have been researched, the semantic basic components of their creation have been defined. It has been studied that in a living dialectal language there are permanent renovations of the forms and semantics, emerging from the new motivations, the development of the lexical variants on the basis of the existing constructions.

Key words: phrazeological unit, semantics, motivations, dialect, Easter holidays. 
$\mathrm{H}$ аціональну мову неможливо пізнати без дослідження лінгвістичного аспекту обрядовості, що $\epsilon$ важливим складником культурнонаціонального життя. Традиції, звичаї та обряди, нагромаджені впродовж історичного розвитку етносу, є багатовимірним і надійним джерелом для багатьох галузей науки.

У працях В. Мокієнка, В. Лавера, М. Демського, В. Ужченка, Д. Ужченка, Г. Аркушина, А. Івченка та ін. обгрунтовано важливе місце діалектної фразеології в системі філологічної науки, доведено, що фразеологічний склад мови якнайтісніше пов'язаний із культурою та світоглядом етносу.

Незважаючи на активізацію досліджень з лексики та фразеології українського діалектного мовлення, що спостерігаємо в останні десятиліття, обрядовозвичаєва фразеологія ще й досі залишається майже поза увагою українських діалектологів. Окремі тематичні групи фразем описані на матеріалах обрядів весілля у східнополіських говірках ${ }^{1}$, закарпатських ${ }^{2}$, гуцульських ${ }^{3}$, східнослобожанських ${ }^{4}$; поховальних обрядодій - у середньополіських говірках ${ }^{5}$; етапів родильного обряду - у поліських говірках ${ }^{6}$ та гуцульських ${ }^{7}$.

Матеріали $з$ різних територій України ще недостатньо представлені в лексикографічних працях, відсутні дослідження фразеологічних одиниць із компонентами - назвами українських календарних свят і звичаїв, тому мета цієї статті - проаналізувати фразеологізми, у складі яких є компоненти, що номінують власне Великодні свята чи їхні етапи, дійства, що відображають сакральний код.

Фразеологізми календарних обрядів — це особливі мовні знаки, що виконують не лишу мовленнєву, але й культурну функції, адже вони образно передають інформацію про людину, іiі навколишній світ і одночасно транслюють культурний зміст, стереотипні уявлення тощо. Для лінгвокраїнознавства важливою $\epsilon$ національно-культурна семантика обрядових фразеологізмів, тобто зміст, що відбиває особливості духовності, обрядів та звичаїв народу - носія мови.

Найбільшим святом після Різдва Христового є Великдень, або Великодні свята, шо святкуються в Україні ще 3 Х ст. ${ }^{8}$ Це одне 3 найбільших християнських свят, приурочене воскресінню Христа. Починається обряд удосвіта сповісткою священика “Христос воскрес!”, після чого він освячує паски і крашанки. Тоді люди розходяться по домівках, щоб сповістити велику радість “Христос воскрес!”.

Матвій Номис у збірці Українські прислів'я, приказки і таке інше подав записаний Степаном Руданським на території Поділля вираз раз у рік Великдень,

${ }^{1}$ П. Ф. Романюк, Лексика весільного обряду Правобережного Полісся, [в:] Дослідження з української діалектології, Київ 1991, с. 225-251.

${ }^{2}$ В. І. Лавер, Фразеологізми в украӥнських говорах Закарпаття, пов'язані з народними обрядами заручин і весілля, [в:] Культура і побут населення Украӥнських Карпат, Ужгород 1973, c. $248-253$.

${ }^{3}$ М. В. Бігусяк, Із спостережень над обрядовою фразеологією гуиульських говірок, [в:] Сучасні проблеми мовознавства та літературознавства, Ужгород 2001, вип. 4, с. 109-111.

${ }^{4}$ I. Магрицька, Семантична структура і культурна мотивація весільних фрразеологізмів у східнослобожсанських говірках, [в:] Діалектологічні студії. 2: Мова і культура, Львів 2003, с. 182-193.

${ }_{5}^{5}$ В. Л. Конобродська, Номінація поліського поховального обряду, [в:] Украйнський діалектологічний збірник, книга 3: Пам'яті Тетяни Назарової, Київ 1997, с. 428-458.

${ }^{6}$ С. Толстая, Из полесской обрядовой лексики: нашлось дитя, [в:] Украйнський діалектологічний збірник, книга 3: Пам'яті Тетяни Назарової, Київ 1997, с. 287-293.

${ }^{7}$ М. В. Бігусяк, 3 лексики родильного обряду у гуиульських говірках, [в:] Український діалектологічний збірник, книга 3: Пам'яті Тетяни Назарової, Київ 1997, с. 293-301.

${ }^{8}$ В. В. Жай воронок, Знаки української етнокультури, словник-довідник, Київ 2006, с. 69.

${ }^{9}$ В. Скуратівський, Вінець, Київ 1994, с. 88. 
що образно передає розуміння законів світу, неможливість щось знову зробити чи доробити, повернути втрачене в часі та ін. ${ }^{10}$

Те, що Великодні свята припадають на час початку весни (період з 22 березня / 4 квітня по 25 квітня / 8 травня) ${ }^{11}$, відбито в основі семантики фразеологізму говірок Південної Волині як Тарас гусіні на Великдень нарвав зі значенням 'дуже мало' 12 . На нашу думку, компонент Великдень передає розуміння реального часу - ранньої весни, коли ще не покрилися листям дерева, а тому не може бути 'багато гусіні'.

Великодні свята - великий комплекс святкувань, якому передували Великий піст, підготовка усього господарства (хати, обійстя тощо), відзначення Вербної неділі. За робо́то̂y̆ тебе́ й вели́кден' на́йде — кажуть на Закарпатті про роботящу людину ${ }^{13}$.

Усі дії передвеликодніх приготувань регламентовані та зберігаються й до сьогодні. Напр., у Велику (Великодню) суботу печуть паски, які присвячують усім живим, готують писанки ${ }^{14}$. У словнику фразеологізмів південноволинських говірок зафіксовано вираз у Великодну суботу з кужелем до хати на позначення поняття 'виконувати незначну роботу, коли є важливіші справи'15. Ідеться про порушення давніх традицій цього дня, важливість виконання певних робіт саме в цей день.

У с. Сивороги Дунаєвецького району Хмельницької області записано такий

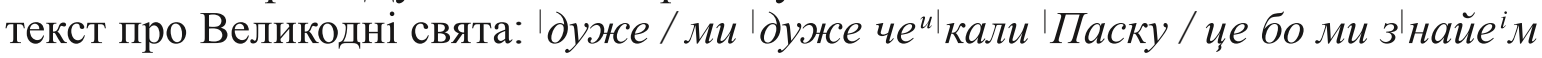

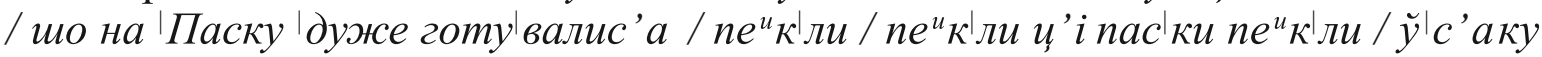

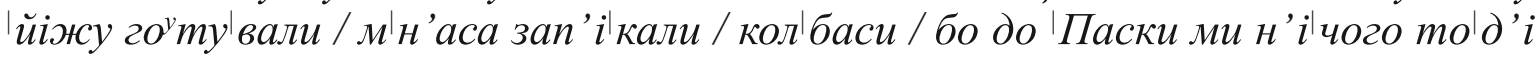
не ${ }^{u}$ 'йіли / ско'ромно так / 'постиели // ну йак' постиели / 'йіли / а'ле бо' йалис' а

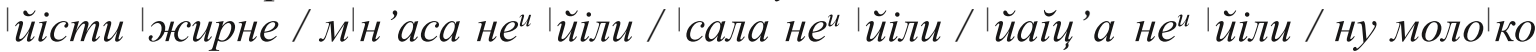

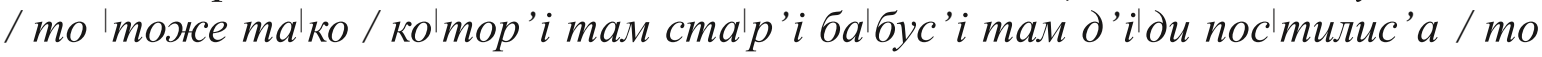
бо'йалис' ' 'йісти 'жирне / такеи| во там ўс'о на о' ужсе так ску'чали за иеец̆ 'дуже че и| кали / ко'ли ие ўже 'будут' с'в' ${ }^{\mid}$'та / 'Паска // а ууже на 'Паску йак

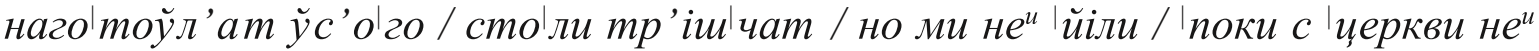
приени еу сут с'в' а ченого / m| реба спо чатку по йісти с'в' а ченого.

Отже, на це християнське свято готували багато страв, і після довготривалого сорокаденного посту люди могли наїстися, а дехто й не міг спинися у споживанні страв і напоїв, утрачаючи почуття міри. У ці дні й сироти могли теж наістися, бо подавати бідним було звичаєм. Тому невипадково в усному мовленні 3'явилися фразеологізми: наїстися як сиро́хман (сиро́та) на Вели́лдень 'надмірно їсти' ${ }^{16}$, опьввся як сиро́та на Вели́гдень 'дуже п'яний' ${ }^{17}$, наїстися як сирохма́н на Вели́лдень ${ }^{18}$; опи́вся як сиро́та на Вели́лдень ${ }^{19}$.

${ }^{10}$ Приказки, прислів'я, і таке інше, уклав М. Номис, Київ 1993, с. 215.

${ }^{11}$ В. В. Жайворонок, Знаки української етнокультури..., с. 67.

${ }^{12}$ Н. В. Кірілкова, Словник волинської фразеологї̈, Острог-Рівне 2013, с. 167.

${ }^{13}$ В. И. Лавер, Семантико-структурные варианты диалектных фразеологизмов в южнокарпатских говорах и их лингвогеографическая интерпретация, [в:] „Вопросы фразеологии”, Самарканд 1975, вып. 272, № 8, с. 181.

${ }^{14}$ С. О. Черепанова, Філософія родознавства, Київ 2008, с. 204.

${ }^{15}$ Н. В. Кірілкова, Словник волинської фразеологї..., с. 165.

${ }^{16}$ Г. Ф. Ступінська, Фразеологія лемківського говору украӥнської мови, дис. .... канд. філол. наук, Івано-Франківськ 2000, с. 150.

${ }^{17}$ Там само, с. 82.

${ }^{18}$ Н. Д. Вархол, А. О. Івченко, Фразеологічний словник лемківських говірок Східної Словаччини, Братислава 1990, с. 26.

${ }^{19}$ Там само, с. 26. 
У говірках Буковини діалектологи записали сталі вирази з опорним компонентом паска, напр.: не могла діждатись, як гречаной паски, в основі якого опора на неіснуючу гречану паску ${ }^{20}$; поживився, як пес паскою 'зазнати невдачі; мало заробити'21 — один 3 прикладів явища фразеологічної енантіосемії. Зауважимо, що у фразеології сучасних українських говірок спостерігають численні приклади енантіосемії, що є основою іронічних висловлень, пов'язаних переважно $з$ характеристикою найвищого вияву ознаки чи стану. Прихована антонімія в таких одиницях, як правило, уживається для іронічної характеристики, а внутрішня антонімія пов'язана з буквальним значенням, що вступає в опозицію 3 асоціаціями, які викликані переносним фразеологічним значенням 22 .

Отже, у вищеназваній фразеологічній одиниці антонімічними є супровідне слово поживився та частина як пес паскою. В основі виразу те, що паска - особливий ритуальний та освячений хліб, який не дають їсти тваринам.

Перед тим, як сідати за стіл, дівчата вмивались водою із крашанками, щоб рум’яними щодня були щоки, тому в народній фразеології красу дівчини часто порівнюють із красою великодньої писанки чи крашанки. Червоне яйце (крашанка) - ознака радості загалом, а великодньої особливо; писанка — розмальоване великоднє куряче або декоративне, звичайно дерев'яне, яйце. Саме розписане яйце символізує джерело життя, усього живого 23.

У гуцульських говірках, як і в інших українських, досить поширеним $\epsilon$ фразеологізм йак' писанка (на Ве'лигден') на позначення 'вродлива, красива'24. Семантичний ряд 'вродлива' об'єднує фразеологізми, у значенні яких сема 'вродлива'. Це пререважно компаративні сполуки, експресивність яких залежить від ступеня образності, що твориться внутрішньою формою. Фразеологізмам зі значенням 'вродлива' властива позитивна оцінка та суб'єктне оточення іменник, займенник, субстантивовані слова інших частин мови на позначення особи. У функції супровідних слів найчастіше виступають прикметники: гарна, красна, файна. Значення фразеологізмів може ускладнюватися додатковими семами: 'рум'яна', 'здорова'. Ця модель гарна + як + мистецький виріб = 'дуже гарна' має наддіалектний характер, про що свідчать, зокрема й приклади літературної мови, порівн.: гарна як лялька, гарна як крашанка, гарна як писан$\kappa a$. Основою для мотивації значення слугують асоціативні знання, де червоний колір - символ здоров'я, життя.

У сучасних говірках Південної Волині зафіксовано новий фразеологізм розкрасити, як писанку зі значенням 'побити (із синцями)' 25.

Фразеологізми семантичного ряду 'добрий' характеризують людину, яка наділена позитивними людськими якостями, зокрема добротою. Рідше вони номінують щедру людину, хоч загалом на фразеологічному рівні чіткого розмежування цих якостей не виявлено. Ступінь експресивності цих фразеологізмів залежить від конотативної модальності, вони вимагають суб' єктного оточення, вираженого іменником, займенником, субстантивованими

${ }^{20}$ Буковинські говірки: хрестоматія діалектних текстів, укл. Н. Руснак, Н. Гуйванюк, В. Бузинська, Чернівці 2006, с. 378.

${ }^{21}$ Там само, с. 379.

${ }^{22}$ Н. Д. Коваленко, Енантіофраземи-іроніми в діалектному мовленні, [в:] „Наукові праці Кам'янець-Подільського національного університету імені Івана Огієнка. Філологічні науки", Кам' янець-Подільський 2012, вип. 29, ч. 1, с. 34.

${ }^{23}$ В. В. Жайворонок, Знаки української етнокультури..., с. 451.

${ }^{24}$ М. Я. Олійник, Фразеологія гуцульських говірок, дис. ... канд. філол. наук, Львів 2002, c. 59 .

${ }^{25}$ Н. В. Кірілков а, Словник волинської фразеологї..., с. 120. 
словами інших частин мови на позначення особи. У гуцульських говірках

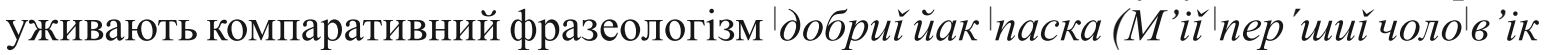
/ то ни те шо д pугий / та той буў'добрий йак' паска / але шо / йак' рано ўмер), що доповнює загальноукраїнську структурно-семантичну модель добрий / такий +

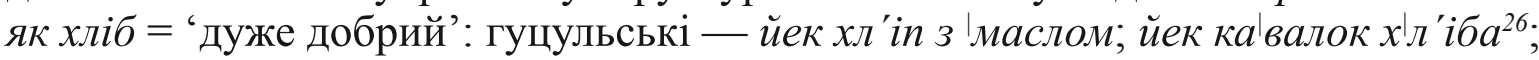
лемківські - добрий як з маслом хліба ${ }^{27}$; добрий як фалаток хліба ${ }^{28}$.

За опублікованими лексикографічними працями, найчастіше 3 опорним словом паска вживають сталі вирази в лемківських говірках, напр.: ззісти вельо пасок 'потрібно багато часу для здійснення певних намірів': - O, та тому дітваковы ищчи бы ззісти вельо пасок, хььбаль втовди му дашто ся вдаст ${ }^{29}$; як кебы паску ззісти 'виявляти неприязне ставлення до кого-небудь' ${ }^{30}$.

Фразеологічний словник украӥнської мови фіксує одиницю як (ніби, мов) на Великдень зі словами вдягнутися, прибратися + 'дуже пишно, по-святковому'31, у якій відбито народний звичай одягатися в усе нове, гарне і святкове. Натомість у говірках Західного Полісся побутує вираз вдітися як серун на Великдень, коли говорять про неохайно вдягнену, брудну дівчину / жінку ${ }^{32}$.

Описуючи фраземи на позначення поняття 'ніколи', дослідники визначають структурно-семантичну фразеомодель на + день святого (иерковне свято). Така модель має кілька типів образної мотивації, які умовно поділимо на групи: це фразеологізми, у яких використано імена 1) справжніх християнських святих та 2) святих фіктивних ${ }^{33}$.

Іншу структурно-семантичну модель на фіктивне християнське свято = 'ніколи' А. Івченко визначає на основі таких прикладів: на маленького Юрія, на маленького Петра, на жидівського Юря, на кінського Петра. Такий фразеологізм, як на кінський Великдень, зі значенням 'ніколи', відносять до тих, що слугують для номінації неіснуючих свят.

Професор С. Килимник у праці Український рік у народніх звичаях в історичному освітленні описує Кінський Великдень (святих Флора й Лавра 18 серпня за старим стилем). Хоч основа цього свята невідома, але відзначався Кінський Великдень ще в кінці XIX ст.: свяченою водою кропили коней, напували їх, дякували за щиру роботу влітку біля ріллі; отже, господарі гостинно вітали коней і жадали від них, щоб любили працю та робили хліб святий. На Київщині в кінці XIX ст. господарі виводили своїх коней на майдан, і священик після спеціальної служби кропив тварин спеціальною водою ${ }^{34}$. Мабуть, через те, що звичай дуже давній, він і втратив уже своє побутування, сучасні мовці сприймають його як неіснуюче, придумане та нереальне свято. У Словнику

${ }^{26}$ М. Я. Олійник, Фразеологія гуцульських говірок..., с. 104.

${ }^{27}$ Г. Ф. Ступінська, Я. В. Битківська, Фразеологічний словник лемківських говірок, Тернопіль 2013, с. 138.

${ }^{28}$ Там само.

${ }^{29}$ Там само, с. 102.

${ }^{30}$ Там само.

${ }^{31}$ Словник фразеологізмів украӥнської мови, за ред. В. М. Білоноженка, І. С. Гнатюк та ін., Київ 2003, с. 56.

32 3. Мацюк, Що сільц̧е, то нове слівце: словник фразеологізмів Західного Полісся, Луцьк 2013, c. 187.

33 А. О. Івченко, Темпоральна фразеологія украӥнських народних говорів: ономасіологічний аналіз семантичних рядів 'ніколи' $i$ 'дуже давно', [в:] Сучасні проблеми мовознавства та літературознавства, Ужгород 2000, вип. 2, с. 115.

${ }^{34}$ С. Килимник, Український рік у народних звичаях в історичному освітленні, у 5 томах, Вінніпег-Торонто 1964, т. 5, с. 139. 
фразеологізмів украӥнської мови теж міститься стаття до фразеологізму на Рахманський Великдень зі значенням “ніколи” ${ }^{35}$; у говірках Буковини на кінський великдень 'невідомо коли, ніколи' ${ }^{36}$.

Отже, фразеологізми 3 досліджуваними компонентами як особливі мовні знаки підтверджують виражену національну самобутність діалектного мовлення; очевидним є факт повного збігу семантики, компонентного складу та структури деяких фразем у літературній мові та діалектах. Деякі обрядодії можуть утратитися, вийти з активного вжитку, але на рівні фразеологічному все ж бути центром інформаційного висловлення.

Обрядофраземи (вислови, що постали як наслідок фразеологічної вербалізації обрядових особливостей, дій чи етапів) демонструють фразеотворчі можливості в переосмисленні сакрального. Усі складники календарних обрядів утворюють понятійне поле, співвідносне з полем номінативним, а значення фразем випливає із контекстів, у яких обрядова дійсність інтерпретує смислову й культурну інформацію цілої нації.

Важливим сьогодні $є$ створення лексикографічних описів обрядової фраземіки говірок як важливого кроку в побудові класифікації на матеріалі українського діалектного континууму, що дасть змогу в майбутньому 3 максимальною ефективністю використати дані в порівняльних, ареальних та етимологічних дослідженнях із української та слов'янської фраземіки. Розглядаючи лексику й фразеологію обрядів, потрібно подавати структуру цих обрядів, їхню інваріантну модель та характеризувати особливості реалізації їх у різних регіонах.

\section{Список використаної літератури}

Бабич Н. Д., O фразеологическом словаре буковинских говоров [в:] „Вопросы фразеологии", тр. СамГУ, Самарканд 1975, вып. 272, № 8, с. 5-13.

Бігусяк М. В., 3 лексики родильного обряду у гуиульських говірках, [в:] Украйнський діалектологічний збірник, книга 3: Пам'яті Тетяни Назарової, Київ 1997, с. 293 301.

Бігусяк М. В., Із спостережень над обрядовою фразеологією гуиульських говірок, [в:] „Сучасні проблеми мовознавства та літературознавства”, Ужгород 2001, вип. 4, c. $109-111$.

Буковинські говірки: хрестоматія діалектних текстів, укл. Н. Руснак, Н. Гуйванюк, В. Бузинська, Чернівці 2006.

Вархол Н. Д., Івченко А. О., Фразеологічний словник лемківських говірок Східної Словаччини, Братислава 1990.

Жайворонок В. В., Знаки украӥнської етнокультури, словник-довідник, Київ 2006.

Івченко А. О., Темпоральна рразеологія українських народних говорів: ономасіологічний аналіз семантичних рядів 'ніколи' $i$ 'дуже давно', [в:] „Сучасні проблеми мовознавства та літературознавства”, Ужгород 2000, вип. 2, с. 114-122.

Килимник С., Украӥнський рік у народних звичаях в історичному освітленні, у 5 томах, Вінніпег-Торонто, т. V. Осінній цикль, 1963.

Кірілкова Н. В., Словник волинської фразеології, Острог-Рівне 2013.

Коваленко Н. Д., Енантіофраземи-іроніми в діалектному мовленні, [в:] „Наукові праці Кам'янець-Подільського національного університету імені Івана Огієнка. Філологічні науки", Кам’янець-Подільський 2012, вип. 29, ч. 1, с. 33-35.

${ }^{35}$ Словник фразеологізмів украӥнської мови, Київ 2003, с. 56.

${ }^{36}$ Н. Д. Бабич, О фразеологическом словаре буковинских говоров, [в:] „Вопросы фразеологии", тр. СамГУ, Самарканд 1975, вып. 272, № 8, с. 7. 
Конобродська В. Л., Номінація поліського поховального обряду, [в:] Український діалектологічний збірник, книга 3: Пам'яті Тетяни Назарової, Київ 1997, с. 428458.

Лавер В. И., Семантико-структурные варианты диалектных фразеологизмов в южнокарпатских говорах и их лингвогеографическая интерпретачия, [в:] „Вопросы фразеологии”, Самарканд 1975, вып. 272, № 8, с. 178-191.

Лавер В. І., Фразеологізми в українських говорах Закарпаття, пов'язані з народними обрядами заручин і весілля, [в:] Культура і побут населення Украӥнських Карпат, Ужгород 1973, с. 248-253.

Магрицька I., Семантична структура і культурна мотивачія весільних фразеологізмів у східнослобожанських говірках, [в:] Діалектологічні студї, т. 2: Мова і культура, Львів 2003, с. 182-193.

Мацюк 3., Що сільце, то нове слівце: словник фразеологізмів Західного Полісся, Луцьк 2013.

Олійник М. Я., Фразеологія гуцульських говірок, дис. ... канд. філол. наук, Львів 2002.

Приказки, прислів'я, і таке інше, уклав М. Номис, Київ 1993.

Романюк П. Ф., Лексика весільного обряду Правобережного Полісся, [в:] Дослідження з украӥнської діалектологї, Київ 1991, с. 225-251.

Скуратівський В., Вінець, Київ 1994.

Словник фразеологізмів української мови, за ред. В. М. Білоноженка, І. С. Гнатюк та ін., Київ 2003.

Ступінська Г. Ф., Фразеологія лемківського говору украӥнської мови, дис. ... канд. філол. наук, Івано-Франківськ 2000.

Ступінська Г. Ф., Битківська Я. В., Фразеологічний словник лемківських говірок, Тернопіль 2013.

Толстая С., Из полесской обрядовой лексики: нашлось дитя, [в:] Украӥнський діалектологічний збірник, книга 3: Пам'яті Тетяни Назарової, Київ 1997, с. 287-293.

Черепанова С. О., Філософія родознавства, Київ 2008.

\section{Spysok vykorystanoi literatury [References]}

Babich N. D., O frazeologicheskom slovare bukovinskih govorov [About Phraseological Dictionary of Bukovyna Dialects], [v:] „Voprosy frazeologii”, tr. SamGU, Samarkand 1975, vyp. 272, № 8, s. 5-13.

Bihusiak M. V., Z leksyky rodylnoho obriadu u hutsulskykh hovirkakh [Lexis of Family Rites of Hutsul Dialects], [v:] Ukrainskyi dialektolohichnyi zbirnyk, knyha 3: Pamiati Tetiany Nazarovoi, Kyiv 1997, s. 293-301.

Bihusiak M. V., Iz sposterezhen nad obriadovoiu frazeolohiieiu hutsulskykh hovirok [On Observation of Rite Phraseology of Hutsul Dialects], [v:] ,Suchasni problemy movoznavstva ta literaturoznavstva", Uzhhorod 2001, vyp. 4, s. 109-111.

Bukovynski hovirky: khrestomatiia dialektnykh tekstiv [Dialects of Bukovyna], ukl. N. Rusnak, N. Huivaniuk, V. Buzynska, Chernivtsi 2006.

Varkhol N. D., Ivchenko A. O., Frazeolohichnyi slovnyk lemkivskykh hovirok Skhidnoi Slovachchyny [Phraseological Dictionary of Lemky Dialect of Eastern Slovakia], Bratyslava 1990.

Zhaivoronok V. V., Znaky ukrainskoi etnokultury [Signs of Ukrainian Ethnic Culture], slovnyk-dovidnyk, Kyiv 2006.

Ivchenko A. O., Temporalna frazeolohiia ukrainskykh narodnykh hovoriv: onomasiolohichnyi analiz semantychnykh riadiv "nikoly $i$ 'duzhe davno [Temporal Phraseology Ukrainian Dialects: Onomaciological Analysis of Semantic Groups 'never and 'a long time ago], [v:] „Suchasni problemy movoznavstva ta literaturoznavstva”, Uzhhorod 2000, vyp. 2, s. 114-122. 
Kylymnyk S., Ukrainskyi rik u narodnykh zvychaiakh v istorychnomu osvitlenni [Ukrainian Year in Folk Customs and Historical Description], u 5 tomakh, Vinnipeh-Toronto, t. V, Osinnii tsykl, 1963.

Kirilkova N. V., Slovnyk volynskoi frazeolohii [Dictionary of Volyn Phraseology], OstrohRivne 2013.

Kovalenko N. D., Enantiofrazemy-ironimy $v$ dialektnomu movlenni [Irony-Phrasemes in Dialectal Speech], [v:] „Naukovi pratsi Kamianets-Podilskoho natsionalnoho universytetu imeni Ivana Ohiienka. Filolohichni nauky”, Kamianets-Podilskyi 2012, vyp. 29 , ch. 1 , s. $33-35$.

Konobrodska V. L., Nominatsiia poliskoho pokhovalnoho obriadu [Nomination of Polish Burial Ceremony], [v:] Ukrainskyi dialektolohichnyi zbirnyk, knyha 3: Pamiati Tetiany Nazarovoi, Kyiv 1997, t. 1, s. 428-458.

Laver V. I., Semantiko-strukturnye varianty dialektnyh frazeologizmov v juzhno-karpatskih govorah $i$ ih lingvogeograficheskaja interpretacija [Semantic, Structural Variants of Dialectal Phraseologisms in Southern Carpathian Dialects and their Linguistic Interpretation], [v:] „Voprosy frazeologii”, Samarkand 1975, vyp. 272, № 8, s. 178-191.

Laver V. I., Frazeolohizmy v ukrainskykh hovorakh Zakarpattia, poviazani z narodnymy obriadamy zaruchyn i vesillia [Phraseologisms in Ukraibian Dialects of Transcarpathia Connected with Engagement Rites and Wedding], [v:] Kultura i pobut naselennia Ukrainskykh Karpat, Uzhhorod 1973, s. 248-253.

Mahrytska I., Semantychna struktura $i$ kulturna motyvatsiia vesilnykh frazeolohizmiv u skhidnoslobozhanskykh hovirkakh [Semantic Structure and Cultural Motivation of Wedding Phraseologisms in Eastern Slobozhan Dialects], [v:] Dialektolohichni studii, t. 2: Mova i kultura, Lviv 2003, s. 182-193.

Matsiuk Z., Shcho siltse, to nove slivtse: slovnyk frazeolohizmiv Zakhidnoho Polissia [Shcho siltse, to nove slivtse : Dictionary of Phraseologisms of Western Polissia], Lutsk 2013.

Oliinyk M. Ya., Frazeolohiia hutsulskykh hovirok [Phraseology of Hutsul Dialects], dys. ... kand. filol. nauk, Lviv 2002.

Prykazky, pryslivia, i take inshe [Proverbs and Sayings and other], uklav M. Nomys, Kyiv 1993.

Romaniuk P. F., Leksyka vesilnoho obriadu Pravoberezhnoho Polissia [Lexis of Wedding Rite of Pravoberezhnyi Polissia], [v:] Doslidzhennia z ukrainskoi dialektolohii, Kyiv 1991, s. $225-251$.

Skurativskyi V., Vinets [Wreath], Kyiv 1994.

Slovnyk frazeolohizmiv ukrainskoi movy [Dictionary of the Ukrainian Language Phraseologisms], za red. V. M. Bilonozhenka, I. S. Hnatiuk ta in., Kyiv 2003.

Stupinska H. F., Frazeolohiia lemkivskoho hovoru ukrainskoi movy [Phraseology of Lemky Dialect of the Ukrainian Language], dys. ... kand. filol. nauk, Ivano-Frankivsk 2000.

Stupinska H. F., Bytkivska Ya. V., Frazeolohichnyi slovnyk lemkivskykh hovirok [Phraseological Dictionary of Lemky Dialect], Ternopil 2013.

Tolstaya S., Iz polesskoj obryadovoj leksiki: nashlos' ditya [From Polissya Rite Lexis: the Child has been Found], [v:] Ukrainskyi dialektolohichnyi zbirnyk, knyha 3: Pamiati Tetiany Nazarovoi, Kyiv 1997, s. 287-293.

Cherepanova S. O., Filosofiia rodoznavstva [Philosophy of Generation], Kyiv 2008. 